\title{
Distribution of arsenite-oxidizing bacteria and its correlation with environmental factors in geothermal areas of Tengchong, Yunnan, China
}

\author{
Ping $\mathrm{Li}^{1,{ }^{*}}$, Dawei Jiang ${ }^{1}$, and Zhou Jiang ${ }^{1,2}$ \\ ${ }^{1}$ State Key Laboratory of Biogeology and Environmental Geology, China University of Geosciences, \\ Wuhan, China \\ ${ }^{2}$ School of Environmental Studies, China University of Geosciences, Wuhan, China
}

\begin{abstract}
Arsenic (As) is an ubiquitous constituent in geothermal water. Arsenite (As III) is oxidized via microbial processes as the waters equilibrate with oxygen in the geothermal effluent. The distribution of arsenite oxdizing bacteria and its correlation with environment factors were studied in Tengchong geothermal areas of Yunnan, China. A total of 230 aioA clone sequences were obtained and these sequences were affiliated with four phyla: Betaproteobacteria, Alphaproteobacteria, DeinococcusThermus and Aquificae. Temperature was negatively correlated with aioA diversity and was the only environment factor that had correlation with diversity index. Betaproteobacteria was mainly distributed in low temperature $\left(\mathrm{T}=28\right.$ to $\left.43{ }^{\circ} \mathrm{C}\right)$ and circumneutral or light alkaline $(\mathrm{pH}=7$ to 9) springs; Alphaproteobacteria was mainly predominant in low $\mathrm{pH}(\mathrm{pH}$ $=3.3$ to 3.6) springs; Deinococcus-Thermus and Aquificae mainly inhabited in high temperature $\left(\mathrm{T}=55\right.$ to $\left.78^{\circ} \mathrm{C}\right)$ springs with a wide range of $\mathrm{pH}$. Usually, Deinococcus-Thermus was dominant when springs had a $\mathrm{pH}$ within 4.0 to 8.0. Aquificae was dominated in springs with $\mathrm{pH}>8.0$ or $\mathrm{pH}$ $<4.0$.
\end{abstract}

\section{Diversity of aioA gene}

A total of 230 aioA gene clone sequences from 10 sample sites were subjected to sequence similarity analysis. The coverage values of the clone libraries were greater than $78 \%$ for all except one sample ZZQ2 for which the coverage was $42 \%$ (Table 1). The quantity of operational taxonomic units (OTUs) in different samples were mostly under 6 , and Chaol diversity indices were not higher than 5.0 except for samples ZZQ2 and SRBZ (20.3 and 9.0, respectively.

The correlation between environmental factors and the microbial diversities indicated by the quantity of OTUs, and the Shannon and Chaol was analyzed using the statistical analysis software SPSS (Table 2). The only statistically significant correlation is for that between temperature and the Shannon index $(\mathrm{P} \leq 0.05$, correlation coefficient -0.654$)$.

\footnotetext{
*Corresponding author: pli@cug.edu.cn
} 
Table 1. Diversity of aioA genes of 10 samples collected from Tengchong (97\% OTU level)

\begin{tabular}{cccccc}
\hline Sample & $\begin{array}{c}\text { Quantity of } \\
\text { clone }\end{array}$ & Coverage & $\begin{array}{c}\text { Quantity of } \\
\text { OTU }\end{array}$ & Shannon & Chaol \\
\hline LXS & 23 & $85 \%$ & 5 & 1.31 & 5.0 \\
XXS & 39 & $95 \%$ & 2 & 0.33 & 2.0 \\
SPS & 19 & $95 \%$ & 1 & 0.00 & 1.0 \\
ZZQ1 & 19 & $95 \%$ & 1 & 0.00 & 1.0 \\
ZZQ2 & 19 & $42 \%$ & 11 & 2.03 & 20.3 \\
LGG1 & 15 & $80 \%$ & 3 & 0.85 & 3.0 \\
LGG2 & 12 & $83 \%$ & 2 & 0.45 & 2.0 \\
SRBZ & 28 & $79 \%$ & 6 & 1.25 & 9.0 \\
HYDW & 37 & $95 \%$ & 2 & 0.52 & 2.0 \\
QLDW & 19 & $79 \%$ & 4 & 1.06 & 4.0 \\
\hline
\end{tabular}

The translated amino acid sequences of the aioA genes were generally classified into five putative groups and affiliated with four phyla (Fig. 1). Group I and Group II belong to Betaproteobacteria. Group III, Group IV and group V belong to Deinococcus-Thermus, Alphaproteobacteria and Aquificae, respectively.

Table 2. Statistical correlations between environmental factors and aioA gene diversities.

\begin{tabular}{cccc}
\hline \multirow{2}{*}{ Environmental factors } & \multicolumn{3}{c}{ Diversity } \\
\cline { 2 - 4 } & OTU & Shannon & Chaol \\
\hline $\mathrm{T}$ & -0.624 & $\mathbf{- 0 . 6 5 4}$ & -0.62 \\
$\mathrm{pH}$ & 0.558 & 0.505 & 0.538 \\
$\mathrm{~S}^{2-}(\mathrm{mg} / \mathrm{L})$ & -0.08 & -0.058 & -0.068 \\
$\mathrm{Na}^{+}(\mathrm{mg} / \mathrm{L})$ & 0.009 & -0.013 & 0.047 \\
$\mathrm{Cl}^{-}(\mathrm{mg} / \mathrm{L})$ & 0.571 & 0.493 & 0.601 \\
$\mathrm{SO}_{4}{ }^{2-}(\mathrm{mg} / \mathrm{L})$ & -0.192 & -0.129 & -0.176 \\
$\mathrm{HCO}_{3}{ }^{-}(\mathrm{mg} / \mathrm{L})$ & -0.226 & -0.183 & -0.217 \\
$\mathrm{Total}_{\mathrm{Fe}}(\mathrm{mg} / \mathrm{L})$ & -0.251 & -0.2 & -0.234 \\
$\mathrm{Total} \mathrm{As}(\mu \mathrm{g} / \mathrm{L})$ & 0.151 & 0.022 & 0.185 \\
\hline
\end{tabular}

+ and -, positive and negative relationship, respectively; ${ }^{*} \mathrm{P}$-value $<0.05$;

\section{Correlation with environmental factors}

Correlations between the aioA gene diversity distributions and environmental factors were examined (Table 3). According to the data, Group II is significantly negatively correlated with temperature $(\mathrm{R}=-0.651, \mathrm{P} \leqslant 0.05)$, but Group IV showed positive correlation with temperature $(\mathrm{R}=0.722, \mathrm{P} \leqslant 0.05)$. The $\mathrm{Cl}$ concentration was significantly positively correlated with Group I and Group II. Group III was significantly correlated with the concentrations of $\mathrm{SO}_{4}{ }^{2-}, \mathrm{Fe}^{2+}$, and total $\mathrm{Fe}$. Other environmental factors, including arsenic 
species and $\mathrm{HCO}_{3}{ }^{-}$, did not show significantly effects on community structure of the aioA gene.

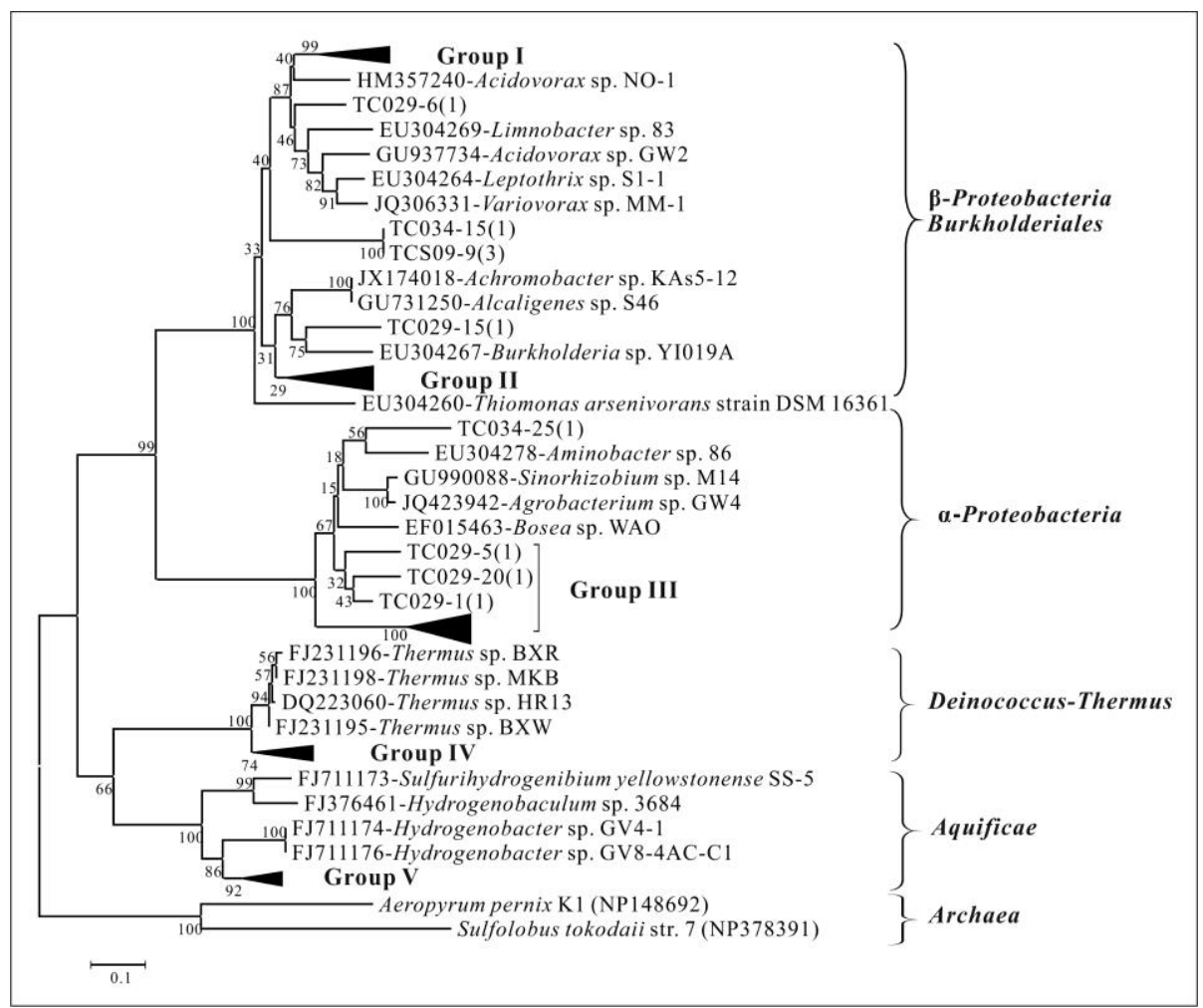

Fig. 1. Phylogeny of aioA sequences deduced from clone sequences detected in hot spring in Yunnan. Lower-case letters show the variety of OTU.

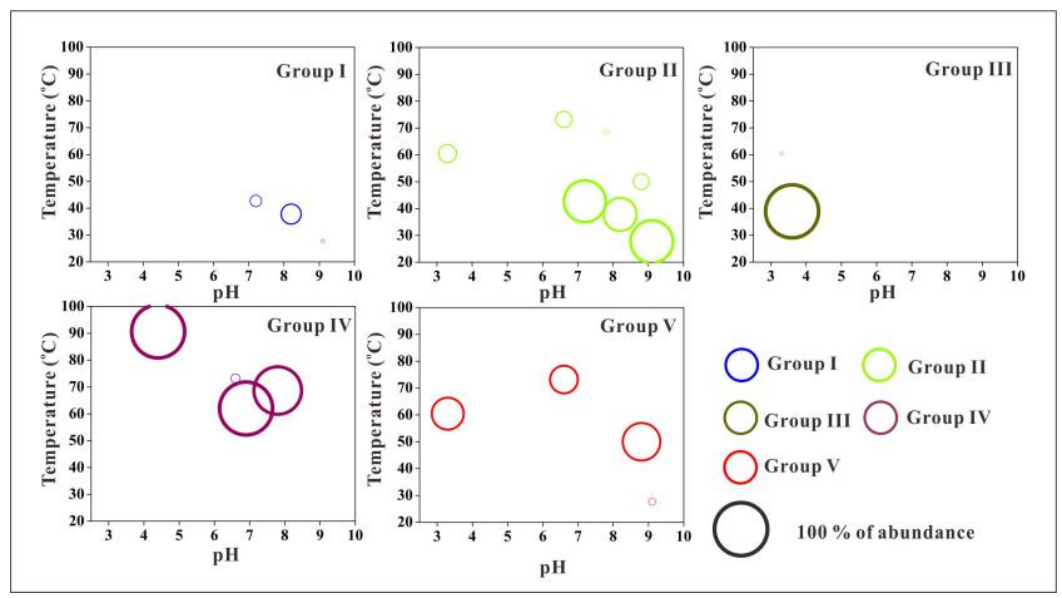

Fig. 2. Relationship between aio A gene group and temperature and $\mathrm{pH}$, wheres the size of each circle represents the proportion of different group in the library. 
The correlations between the aioA gene in our samples and $\mathrm{pH}$ and temperature were analyzed (Figure 2). The data indicated that the Group distribution had a particular relationships with the hot spring temperature and $\mathrm{pH}$. Group I and Group II were mainly distributed in low-temperature and high-pH environments, and Group II had the main advantage in these environments. The temperature distribution range of Group II was wider than the other groups. Group III only appeared in low-pH hot springs. Due to the small number of low-pH sample locations and the small temperature range covered, the correlation between Group III and temperature cannot be determined. Both Group IV and Group V were concentrated in hot springs with high temperatures and had a wide range of $\mathrm{pH}$ adaptability. However, in the range of $\mathrm{pH} 4.0-8.0$, Group IV was usually dominant in hot springs, while Group V existed in more extreme environments with $\mathrm{pH}<4.0$ or $\mathrm{pH}>$ 8.0.

Table 3. Statistical correlations between environmental factors and aioA gene groups.

\begin{tabular}{cccccc}
\hline \multirow{2}{*}{$\begin{array}{c}\text { Environmental } \\
\text { factors }\end{array}$} & \multicolumn{5}{c}{ community structure of aioA gene } \\
\cline { 2 - 6 } & Group I & Group II & Group III & Group IV & Group V \\
\hline $\mathrm{T}\left({ }^{\circ} \mathrm{C}\right)$ & -0.492 & $-.779^{* *}$ & 0.073 & $.724^{*}$ & -0.157 \\
$\mathrm{pH}$ & 0.371 & 0.544 & -0.579 & -0.096 & 0.023 \\
$\mathrm{NH}^{4+}(\mathrm{mg} / \mathrm{L})$ & -0.137 & -0.334 & -0.142 & 0.518 & -0.24 \\
$\mathrm{~S}^{2-}(\mathrm{mg} / \mathrm{L})$ & -0.064 & -0.213 & $.943^{* *}$ & -0.366 & -0.184 \\
$\mathrm{Ca}^{2+}(\mathrm{mg} / \mathrm{L})$ & 0.4 & 0.226 & 0.327 & -0.377 & -0.182 \\
$\mathrm{Mg}^{2+}(\mathrm{mg} / \mathrm{L})$ & 0.399 & 0.481 & -0.079 & -0.226 & -0.257 \\
$\mathrm{Na}^{+}(\mathrm{mg} / \mathrm{L})$ & 0.59 & 0.611 & -0.336 & -0.083 & -0.429 \\
$\mathrm{Cl}^{-}(\mathrm{mg} / \mathrm{L})$ & $.875^{* *}$ & $.790^{* *}$ & -0.289 & -0.328 & -0.413 \\
$\mathrm{SO}_{4}^{2-}(\mathrm{mg} / \mathrm{L})$ & -0.245 & -0.25 & $.676^{*}$ & -0.292 & 0.108 \\
$\mathrm{HCO}_{3}-(\mathrm{mg} / \mathrm{L})$ & 0.401 & 0.435 & -0.246 & -0.057 & -0.293 \\
$\mathrm{Fe}^{2+}(\mathrm{mg} / \mathrm{L})$ & -0.122 & -0.319 & $.986^{* *}$ & -0.273 & -0.235 \\
$\mathrm{Total} \mathrm{Fe}(\mathrm{mg} / \mathrm{L})^{-0.174}$ & -0.315 & $.961^{* *}$ & -0.312 & -0.129 \\
$\mathrm{As}^{3+}(\mu \mathrm{g} / \mathrm{L})$ & 0.221 & 0.139 & -0.076 & 0.164 & -0.423 \\
$\mathrm{Total} \mathrm{As}(\mu \mathrm{g} / \mathrm{L})^{*}$ & 0.036 & -0.01 & -0.373 & 0.482 & -0.362 \\
\hline
\end{tabular}

+ and -, positive and negative relationship, respectively; ${ }^{*} \mathrm{P}$-value $<0.05 ;{ }^{* *} \mathrm{P}$-value $<0.01$.

\section{References}

1. Z. Jiang, et al., Extremophiles. 18, 161-170 (2014)

2. Y. Wang, et al., Appl Geochem, 97, 81-92 (2018)

3. G. Wu, et al., Geomicrobiol J, 32, 482-493 (2015)

4. K. Tang, et al., BMC Genomic, 12, 334 (2011)

5. K. Duquesne, et al., Env Microbiol, 10, 228-237 (2008) 